\title{
A ética da difusão das idéias e a circulação libertária do conhecimento
}

\section{The ethics of ideas diffusion and the free knowledge circulation}

Um indivíduo que se registra como pessoa numa sociedade, reconhece a necessidade de praticar ações que exigirão processos de conhecimento orientados eticamente.

Certamente, ninguém nasce para tornar-se professor, pesquisador ou homem de ciências. Tampouco flanelinha, desempregado ou assaltante. Talvez os homens nasçam para morrerem livres. E certamente os valores morais são a condição necessária para esta liberdade.

A atenção intrínseca para os valores éticos na pesquisa científica se inicia na formação humana do pesquisador. Já deve portanto, há muito estar presente, antes mesmo da formulação da primeira pergunta gerada pela curiosidade. Passa pela tentativa de esgotar o conhecimento existente para estabelecer o seu marco conceitual, bem como para utilizar o instrumento de aferição mais adequado ao seu estudo. A submissão de um projeto de pesquisa aos comitês de ética institucionais deve, naturalmente, ser empreendida como o elogiável e absoluto respeito para com os sujeitos participantes. E a divulgação dos seus resultados, como um compromisso ético e social: um amplo e solidário compartilhamento do conhecimento.

Nesta fase se insere a responsabilidade da editoria de uma revista científica. Cabe a ela estabelecer critérios baseados em pressupostos éticos, para que possam ser selecionados os artigos que melhor cumpram a missão de ajudar a desenvolver a sociedade. Não se trata de tarefa simples ou de importância menor, pois não se deve cometer injustiças e desestimular colaboradores. É mister ademais garantir a mais ampla divulgação de um artigo, atingindo um público específico na tentativa de maximizar os efeitos desejados. Discordando do uso do conhecimento como fonte de poder, riqueza ou opressão, e acreditando que a partilha do conhecimento aproxima os homens, um periódico concorre para a justiça e constrói a liberdade.

Estes critérios são fundamentais em qualquer lugar, e como cidadãos, profissionais ou pesquisadores no Brasil, não podemos esquecê-los. É preciso esforço e tenacidade para produzir o melhor e o eticamente correto, apesar das dificuldades.

Os esforços despendidos para editar, em um país latino-americano, uma revista científica dedicada à mulher e à criança, bem podem exemplificar a essência desta afirmação. Ousar contribuir para a construção de um saudável modo de viver e para a prática de uma existência feliz e autônoma, através deste meio de comunicação social, é um exemplo do nosso compromisso.

Desta forma, a Revista Brasileira de Saúde Materno Infantil tenta na sua prática, aproximar a intenção do exercício perene da Ética, com o gesto da sua contribuição para a ciência e para a sociedade.

\section{Gilliat Hanois Falbo Neto}

Departamento de Pesquisa. Instituto Materno Infantil de Pernambuco, IMIP

Rua dos Coelhos, 300, Recife, PE, Brasil. CEP: 50.070-550

E-mail: pesquisa@imip.org.br 